\title{
The Role Of The Development Of Small Business And Private Entrepreneurship In The Provision Of Employment: A Case Study Of The Republic Of Uzbekistan
}

\author{
Ibrgagimov Lutfullo Ziyadullayevich, PhD Student \\ University of Alexandru Ioan Cuza, Iasi, Romania
}

doi: 10.19044/esj.2016.v12n16p94 URL:http://dx.doi.org/10.19044/esj.2016.v12n16p94

\begin{abstract}
This study focuses on the development of small business and private entrepreneurship in the provision of employment for the teaming population of the Republic of Uzbekistan. It is one of the main indicators used in identifying not only the economic situation of the people, but also the lifestyle of the people, especially where they live. One of the main issues affecting the program of employment of the population and in organizing new replacements in Uzbekistan is in paying attention as global tasks of small business and enterprise. However, this aims to increase the role of farm activity, sevice, social and market infrastructure, and the development of other beneficiary types of employment. In this article, the main characteristics of the development of small business were stated. In addition, one of the major problems of the employment of the population was also outlined.
\end{abstract}

Keywords: Small business, private entrepreneurship, credit, incomes of population, new replacements

\section{Introduction}

The process of supporting the employment of population, especially youth employment, is usually common at the State Policy level. However, this is because it is very important for Uzbekistan where the main part of the population consisted of $60 \%$ youth. Thus, it offers great attention to the development of small businesses and private enterprises. Basically, there are two main directed decisions by the state for the youth. Thus, this is a call to the positive usage of the ability level of youth.

The first is the Decision "about additional measures for directing graduaters to entrepreneurship.” 
The second is the Decision "about additional measures which is directed to state policy for youth in the Republic of Uzbekistan." Consequently, it aims to create new job places, and to support in the employment of youth by directing them to small businesses and private entrepreneurship (Abdurakhmonov, 2013).

\section{I.}

The creation of measures for the development of private entrepreneurship in defining the benefits of small businesses conditions, tax, customs and other expenses, in a relatively short period of time as a result of the provision of cheap credit resources, has significantly increase the number of small businesses.

According to the data, the number of registered small businesses consists of only 15.5 thousand in 1992 (Tursunov, 2015). It has established more than 35050 small and micro enterprises; however, for some reasons, 23187 small enterprises and firms were liquidated this year (Boltabayev et al., 2011). In 2014, more than 20 new businesses (farms and small farms) have been established. Thus, the total number was 221.1 thousand units. The number of micro-small businesses were raised into 198.5 and microfirms were 22.6 (Figure 1). In general, during the last years, the number of small businesses was raised by 14.3 times.

Figure 1. The registered number of small business subjects (without farm and small farm, thousand) (2014)

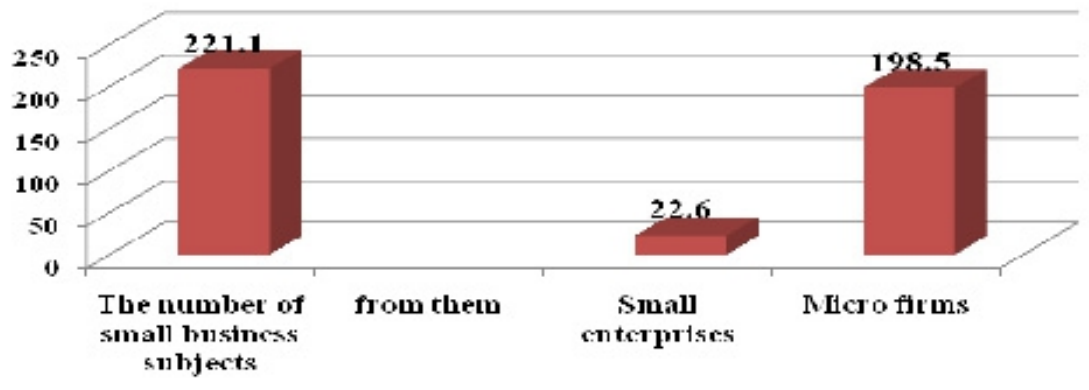

Source: Prepared by author according to the information of State Statistics of the Republic of Uzbekistan

Consequently, one of the priorities of the present reform of the economy is to develop a small business organization which helps to create a class of ownership in Uzbekistan. In order to improve the subject of the small businesses through the use of different methods, the government has implemented support as a priority in this area. Firstly, it is a legal support and a regulatory development. Secondly, the use of financial facilities and 
the development of small business and private entrepreneurship in the sphere of tax reduction which has been established enough, have an important role to play. In addition, the development credits, including micro-credits mechanisms, have been improved and simplified. For instance, realizing the reforms in various sectors of the economy based on the creation of the legal basis has adopted more than 400 legislative acts. Also, this has been implemented consistently as life progresses. Furthermore, one of the most important steps in this direction in order to strengthen the legal framework for business activities of the regulatory system has been formulated. Up till this present time, they are used to simplify and facilitate the functioning of businesses with more than 40 regulatory changes and additions that are done to the document (Karimov, 2016).

Resolutions and Decrees of the President of the Republic of Uzbekistan play an important role in the development and improvement of the business activities in the Republic of Uzbekistan. For instance, it includes the Decree of the President of the Republic of Uzbekistan No PD-1501 on March 11, 2011 "about additional measures of increasing the credit for the subject of small business and private entrepreneurship." Various favorable business conditions and facilities are given like: "about additional measures for the further development of creation of a favorable business environment for small business and private entrepreneurship" on August 24, 2011, Decree No. PD-4354. In addition, it comprises of a number of other regulatory documents for small business and private entrepreneurship. Also, the system of preferential crediting has been simplified.

In order to interest the expansion of the volume of giving credits, it is set free from income tax which was given concessional credit from the expense of a special fund of Commercial bank until January 1, 2016. In the legal framework, the activities of the database of the sector serve as a basis for the development of economic opportunities.

As mentioned above, the second method for the development of the sector is characterized by the usage and the importance of financial application. Subsequently, the consistent development of small business and private entrepreneurship in the country leads to reduction in the tax rates.

\section{Data Analysis}

During the beginning years of independence, tax rates reduced into $38 \%$ and $31 \%$ in 2000 for small business and private entrepreneurship activities. In particular, in 2010, the unique tax rate for small businesses reduced from $8 \%$ to $7 \%$. However, the year 2011 was declared as the "Year of small business and private entrepreneurship" in the Republic of Uzbekistan. Therefore, the adoption of the state program increased the benefit and importance of the private sector in the economy. These 
enterprises in all sectors of the economy, the single tax payment for micro and small enterprises, reduced to $1 \%$ from the current rate of $-7 \%$. Hence, this is defined as $-6 \%$. In 2012, it was reduced to $-5 \%$. In 2012, the single tax rate for small businesses was reduced from $-6 \%$ to $-5 \%$ (Figure 1). We can say that during 1996-2012, tax rate decreased from $-38 \%$ to $5 \%$ or by 7.6 times in the small businesses.

Figure 2. The tax rate for the subject of small businesses (in percent)

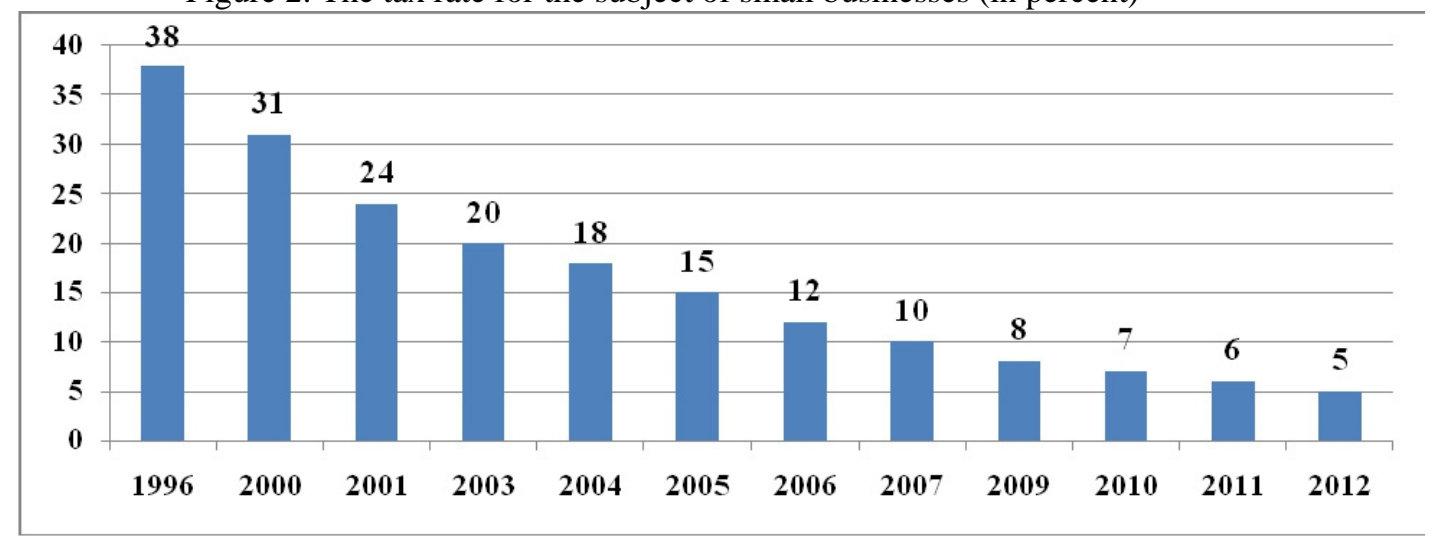

Source: Prepared by author according to the information of State Statistics of the Republic of Uzbekistan

Furthermore, 80 billion dollars and a fund of 300 million dollars, which is used to pay for the deposit state budget subject of small businesses, were left to strengthen their financial capacity (Saydaliyev, 2012). As a result, the capacity of production is growing rapidly. In addition, an income tax rate reduced from $-25 \%$ to $-15 \%$. On the other hand, the single tax rate for the construction reduced from -6\% - to 5\% from January 1, 2015 (Karimov, 2016). A wide range of tax incentives serve as a basis for an increase in the number of subjects in the creation of new job places in the country.

In order to create a more favorable business environment in the country, the framework for the implementation of measures to support small business and private entrepreneurship are continuing. This, in turn, increase the share of small business and private entrepreneurship in the country's GDP. Also, this leads to increase in the share of workers employed in the area. For example, the total employed population was $-49.7 \%$ in 2000 . The share of those working reached $-64.8 \%$ in 2005 , - $74.3 \%$ in 2010 , and - $77 \%$ in 2015. Thus, the share of employment in the area between 2000-2015 increased by 1.5 times. However, you can observe the growth into $-64.5 \%$. Today, it is possible to say that the majority of the employed working population in the same area also indicates the growing role of this sector. 
Effective advantages of small business and private entrepreneurship are been used in the country. Thus, majority of jobs created in the country was done this year. For example, the numbers of new job created in this sector of the economy consist of 476 thousand in 2005, 434.2 thousand in 2005, 600 thousand in 2010, and 480 thousand in 2014. The analysis shows that the number of new jobs of small business and private entrepreneurship is increasing year by year.

To increase the level of employment of population in the country in the new stage of economic reforms and labor market regulation, more complex measures were carried out in the following areas. These include:

1. Labour legislation was being improved. Also, the local employment assistance and social protection of population centers are increasing.

2. To encourage the employees who create new job places to give a tax, credit, and other privileges to them.

3. It is increasing the labor activity of the population, on the basis of the development of population farms and self-employed farmers.

4. The population of the employment and labor market is strengthened. In realizing this, the activity of unprofitable enterprises was postponed, and the works of changing specialties was carried out.

5 . In order to increase the competitiveness of human resources, it should train the quality of the labor force and improve its re-training system.

6. The most effective means of supporting the employment of population, small business and private entrepreneurship, the services sector, and handcraft was developed.

7. It financially supports the population who needs social care; hence, they are established with jobs in the structure of the quota categories.

8. Increased attention to the regulation of internal and external migration.

In our opinion, two functions are very important in the assessment role of small business and private entrepreneurship in the economy of Uzbekistan. The first one is the share of gross domestic product in different regions of the country, while the second one is on the role of employment to keep the place of small business and private entrepreneurship. Thus, small businesses and private enterprise is regarded as an important source of employment and the growth of the GDP.

One of the main indicators of economic development is gross domestic product (GDP). The benefit of small business and private entrepreneurship in the GDP is growing. A proof of this growth can be seen on the information of the percentage of GDP in 1992-2015 of small and private entrepreneurship. It should be noted that the result of the 
implementation of measures increased the share of small businesses in gross domestic product.

Growth of small business and private entrepreneurship in the GDP can be divided into two stages. The first is the period in the early years of independence, up to 1999. If the data is analyzed, the share of the sector is increased. However, it increased in 1992 to $1.4 \%$, in 1994 to 3.4\%, in 1996 to $8.9 \%$, and $28.9 \%$ in 1999 . During this period, it was increased to $27.5 \%$ of the GDP in the sector or 20.6 times (Figure 4).

The second stage is from 2000 up to the present period. However, it was more than 31 percent of the gross domestic product in 2000 . Hence, it is an actively growing share of this sector of the economy. In 2005, this figure decreased to $-38.2 \%$, in 2010 to $-52.5 \%$, in 2012 to $-54.6 \%$, and in 2015 to $-56 \%$. Furthermore, the share of small business and private entrepreneurship in the gross domestic product in 2015 compared to 2000 increased by $25.7 \%$ or 1.8 times (Table 4 ).

Figure 3. The share of small business and private entrepreneurship in the gross domestic product in Uzbekistan (in percent)

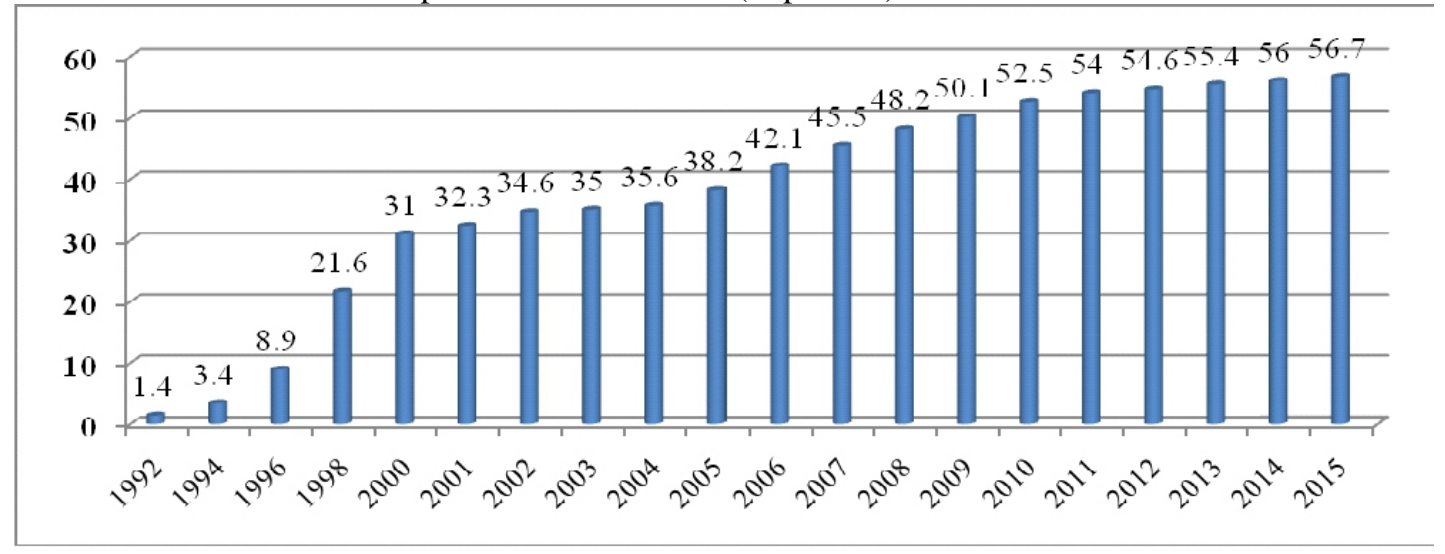

Source: Prepared by author according to the information of State Statistics of the Republic of Uzbekistan

Based on the data mentioned above, the share of small business and entrepreneurship GDP in the country is growing permanently over the years. In particular, the provision of guarantees for the free activity helps to make their registration by the state suitable. In addition, it also facilitates the expansion of the circle in the use of loan funds from the field of favorable factors such as macroeconomic environment. In recent years, there is the growth of the sales of goods and material resources, to purchase and supply conditions, and Gross Savings. Thus, this is as a result of the introduction of the single tax payment instead of financial resources due to the production direction. 
Figure 4. Created volume by small business and entrepreneurship of GDP (in current year, billion sum)

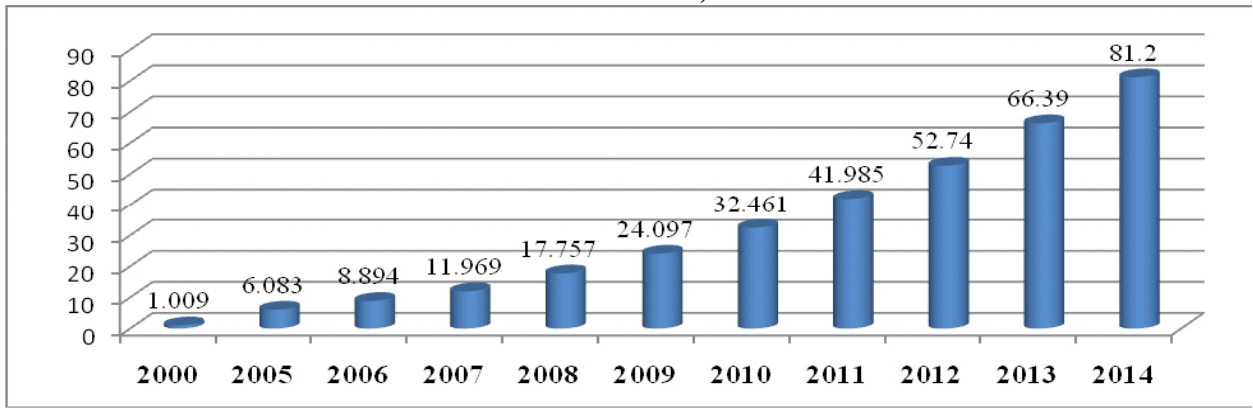

Source: Prepared by author according to the information of State Statistics of the Republic of Uzbekistan

At the moment, a third of the total industrial output in this area are produced i.e. 98 percent of agricultural products (Karimov, 2016).

Therefore, there are a number of preferential mechanisms of external funding entities of small business. These are:

1. Giving credits through external budget funds by the banks. The purpose of credit is to give according to the preferential interest rates of the Banks. However, in any case, it will be smaller than the refinancing rate of the Central Bank.

2. Giving preferable credit is organized through the way of putting some owned parts of incomes to the deposit.

3. To give microcredits to the subjects of small businesses. The advantage of giving microcredits to private sectors is that $50 \%$ funds can be given as cash of credits.

According to the analysis of information, it was the separated amount by the state: 171.5 billion in 2001, 419.9 billion in 2005, 2690.2 billion in 2010, and 9050 billion sum in 2014 (Figure 5).

Figure 5. The amount separated for the development of small business and private entrepreneurship (in billion sum)

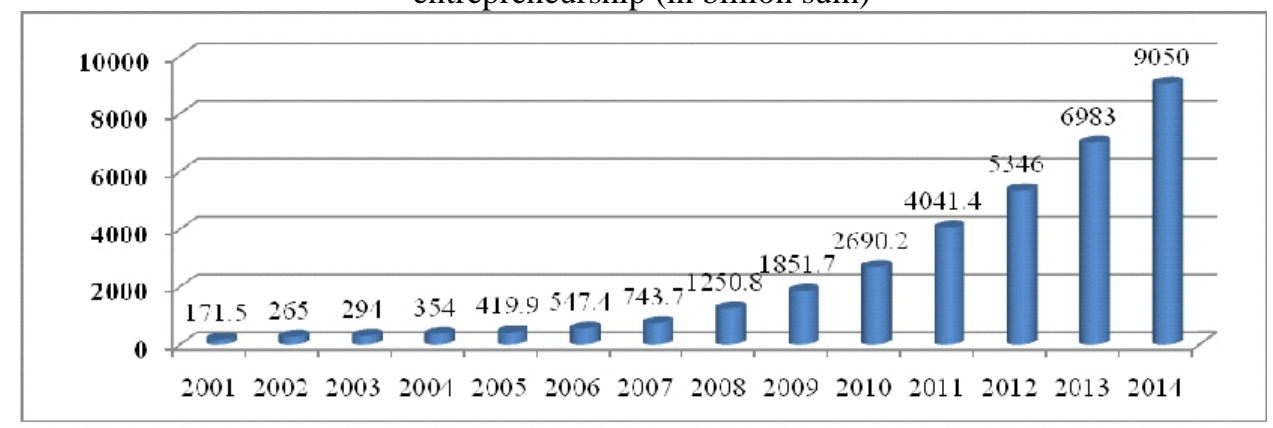

Source: Prepared by author according to the information of State Statistics of the Republic of Uzbekistan 
During 2001-2014, the amount of credits has increased nearly 53 times that of small business and private entrepreneurship. In general, during the last years, the government has allocated a total of 22292 milliard sums for the development of small business and entrepreneurship credits.

Figure 6. Separated volume of micro credits for small business and private (in milliard sum)

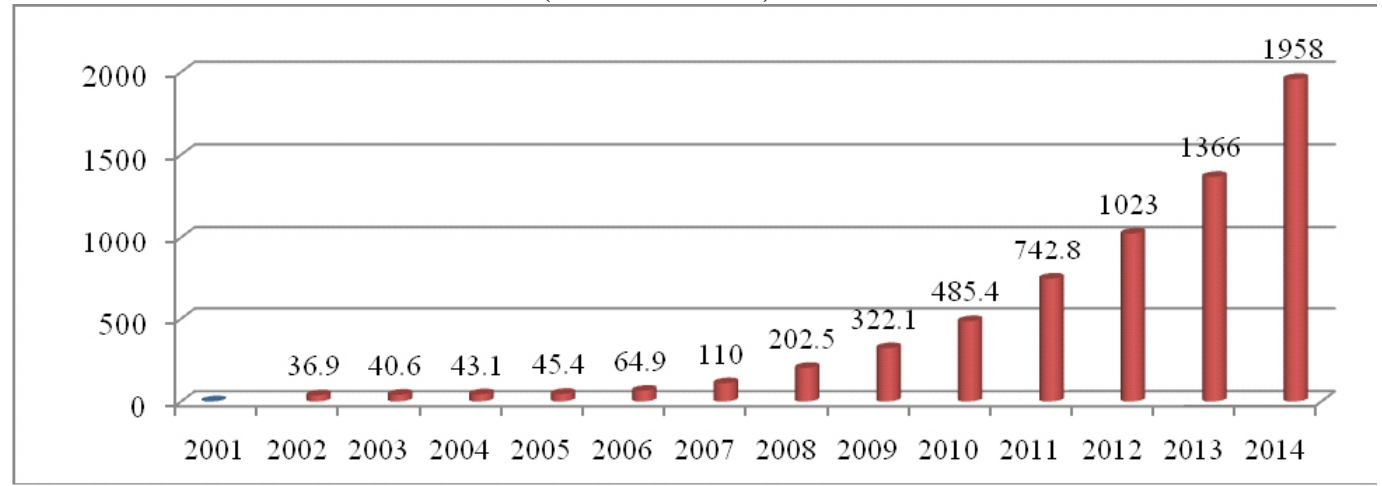

Source: Prepared by author according to the information of State Statistics of the Republic of Uzbekistan

However, a number of priority tasks carried out banking systems in the country in 2014. In particular, it has been improved and it has a simplified allocation mechanism of micro credits. In addition, credits of the subjects of small business and private entrepreneurship was also improved and simplified. There were 9 trillion sums credit and 2 trillion sum micro credits funds allocated to the subjects of small business and private entrepreneurship in 2014 (Figure 6).

The total volumes of credits were increased 25 times. It was also increased 46 times the microcredits of the subjects of small business and private entrepreneurship given by Commercial banks in 2011. It is required to develop new bank services to the subjects of small business and private entrepreneurship. Hence, this is with the aim of creating new job places, liberalization, and modernization of the economy of the country. In this regard, starting from January 1, 2014, the Central Bank lowered the refinancing rate from $12 \%$ to $10 \%$ (Khujakulov, 2015). This, in turn, has been the reason for lowering the rates on the credits to the subjects of entrepreneurship. As a result, these entities through the use of bank credits has created more opportunities for the development of their business.

In recent years, the development of small business and private entrepreneurship in the country has attracted foreign investment. In particular, the large amount of credits has been separated by the Asian Development Bank, Islamic Development Bank, the German Development Bank, the Government of the People's Republic of China, and other foreign 
investors. In November 26, 2010, the President of the Republic of Uzbekistan No. PP-1438 shows "the financial reform of the banking system in 2011-2015 and achieving high international rating and the sustainability of the priority areas." According to the Decree of grants allocated by international financial institutions and foreign governments and credit lines, it amounted to US \$75 million in 2011 and US \$ 155 million in 2015 (Saydaliyev, 2012).

According to the Decree of the President of the Republic of Uzbekistan No. PD-1438 "about financial reform of the banking system in 2011-2015 and achieving high international rating and the sustainability of the priority areas” in November 26, 2010, the amount of grants allocated by international financial institutions and foreign governments and credit lines was 75 million US dollars in 2011 and will be 155 million US Dollars in coming 2015 (Saydaliyev, 2012).

Figure 7. The amount of grants allocated by international financial institutions and foreign governments and credit lines

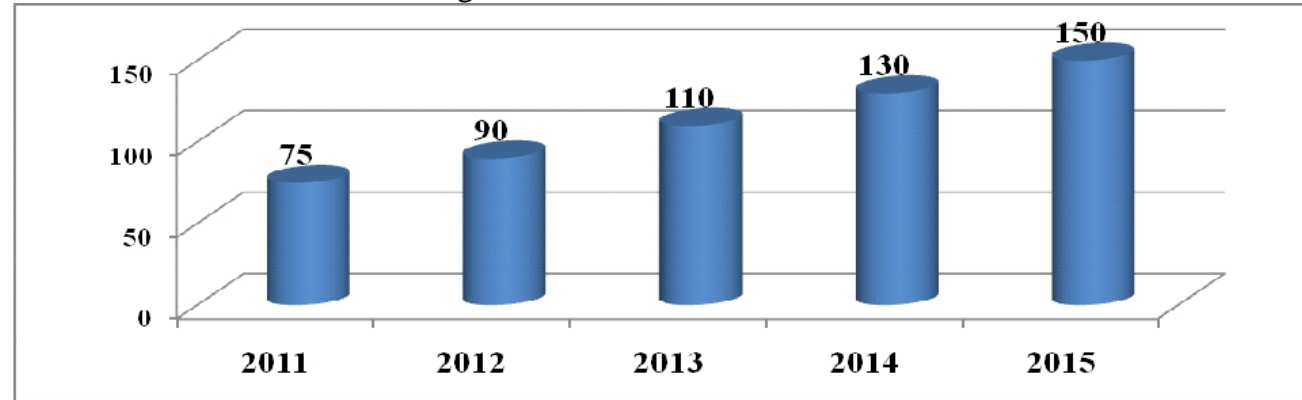

Source: Prepared by author according to the information of State Statistics of the Republic of Uzbekistan

It should be noted that the World Bank's Doing Business ranking of "Small business loans" indicator is in the $42^{\text {nd }}$ place in 2015. It is recorded that in the report by the World Bank to improve the business environment for business activity in the last few years, Uzbekistan achieved the best results among the top ten states in the world (Karimov, 2016).

Today, to study the issues of the production with labor force is a requested economic situation in the country. It is organized starting from the labor market and employment services. Thus, they are busy with unemployment. They account for the structure of vacancies, analysis and future, employment of population, and training. This is aimed to organize employment assistance fund and engagement. In various sectors of the economy, especially in agriculture, structural reforms are implemented between employees and employers. However, this created the legal framework for the regulation of social and labor relations and others. 


\section{Conclusion}

Based on our opinion, the demand for labor in economic activities is increasing. Thus, the most important sectors of the economy are implementing structural reforms. Firstly, this is allowed to develop forms of ownership to raise labor productivity, to create new job places, and beneficiary use of time. Thus, it can be achieved through raising the moral and material interest of workers and the determination of reasonable taxes. At the same time, it requires giving soft loans by the state for the expansion of production and the introduction of advanced technologies. In addition, it consists of the production of agriculture in the period of the market economy. Also, it is used to define public order to the main products of processing industry, development of small business and private entrepreneurship, and funding social works issues. However, sources of financing the development of small businesses are local budget and employment assistance funds.

Today, the benefit of economic reforms in the country is the result of the liberalization of economic life. In many cases, the development of small business is closely bound. It is realizing a number of measures for further development. Also, it is very important to finance with external budget funds investment of the projects of small business.

\section{References:}

Abdurakhmanov (2013). Human development. Textbook. - T.: Economics, p. 542.

Bahromova (2011). The importance of the sphere of small business and private entrepreneurship for social protection of the population. "Economics and innovative technology” scientific electronic magazine. № 2 .

Boltabayev et al. (2011). Small business and private entrepreneurship. Textbook. Ministry of Higher and Secondary Special Education. - T.: TSUE. p.333.

Karimov (2004). Karimov's speech about the final report of socio-economic development of the country in 2003 and deepening of economic reforms in the meeting of the Cabinet of Ministers in 2004 . "Ishonch" newspaper, February 10, vol 22.

Karimov (2013). The main goal is to make large-scale reforms and continue modernization of path. "Khalk suzi" newspaper.

Tursunov (2015). Econometric analysis of the development trends of small business and private entrepreneurship. "Economics and innovative technology” electronic magazine. № 4.

Karimov (2016). To do service for the future of our country - the highest happiness. Tashkent, Uzbekistan. p. 289. 
Saydaliyev (2012). Small business and socio-economic development. "Economics and innovative technology" scientific electronic magazine. № 4. Khujakulov (2015). Statistical analyzes of the development of small business and private entrepreneurship. "Economics and innovative technology" scientific electronic magazine. № 4.

www. lex.uz. (2016). The President of the Republic of Uzbekistan speech about final reports of socio-economic development of the country in 2015 and the most important priorities of economic program for 2016, the results of the meeting of the Cabinet of Ministers.

www. stat.uz 